\title{
MANAJEMEN BERBASIS SEKOLAH UNTUK MENINGKATKAN MUTU PENDIDIKAN DI SMAN 5 KABUPATEN TANGERANG
}

\section{Isar Dasuki Tasim}

SMAN 5 Kabupaten Tangerang

Email: isar_dasuki@yahoo.com

\begin{abstract}
Abstrak : Berbagai lembaga pendidikan di Indonesia seringkali dihadapkan pada rendahnya mutu pendidikan, usaha peningkatan mutu dilakukan dilakukan pemerintah yaitu dengan memberlakukan sebuah manajemen baru yaitu Manajemen Berbasis Sekolah. penelitian ini menggambarkan penerapan manajemen berbasis sekolah untuk meningkatan mutu pendidikan di SMAN 5 Kabupaten Tangerang. Penelitian ini menggunakan penelitian kualitatif dengan metode deskriptif. Penelitian ini menggambarkan tentang 5 aspek yang dapat mendukung keberhasilan penerapan manajemen berbasis sekolah yaitu manajemen kurikulum, manajemen sarana dan prasarana, manajemen kesiswaan, manajemen keuangan, dan penerapan manajemen hubungan masyarakat. 5 aspek tersebut telah diterapkan oleh SMAN 5 Kabupaten Tangerang dengan baik sesuai dengan anjuran dari pemerintah pusat dengan tidak menentang perundang-undangan yang berlaku.
\end{abstract}

Kata Kunci: Manajemen Sekolah, Mutu Pendidikan

Abstract : Various educational institutions in Indonesia was often faced with a low quality of education, efforts to improve the quality are carried out by the government, namely by implementing a new management, namely Managemen Berbasis Sekolah (MBS). This study describes the application of Managemen Berbasis Sekolah (MBS) to improve the quality of education in SMAN 5 Tangerang Regency. This research used qualitative research with descriptive methods. This study describes 5 aspects that can support the successful implementation of school-based management, namely curriculum management, facilities and infrastructure management, student management, financial management, and the application of public relations management. These 5 aspects have been implemented by SMAN 5 Tangerang Regency properly in accordance with recommendations from the central government by not opposing the applicable laws..

Keywords: School Management, Education Quality 


\section{PENDAHULUAN}

Sekolah merupakan tempat siswa untuk menimba ilmu dan tempat berlangsungnya kegiatan pembelajaran dikelas yang dilakukan oleh guru kepada siswa sesuai dengan rencana sekolah yang telah ditetapkan. Agar tercapai tujuan yang telah direncanakan, perlu adanya sinergitas antara pihak sekolah, siswa, wali murid dan masyarakat yang berada di lingkungan sekolah.

Kolaborasi antar sekolah dan masyarakat sekitar akan mendukung jalannya proses pendidikan. Salah satu cara terbaik untuk dapat mencapai tujuan secara maksimal adalah dengan menerapkan salah satu otoritas dalam sekolah yang dihasilkan dari pembaharuan pendidikan yaitu Managemen Berbasis Sekolah (MBS) yang termasuk salah satu model baru dalam pengelolaan pendidikan dan peningkatan mutu pendidikan.

$$
\text { Menurut Sari dkk }
$$

menyatakan bahwa managemen berbasis sekolah merupakan bentuk pola baru yang diwujudkan oleh pemerintah untuk menyerahkan beberapa otoritas kepada sekolah agar bisa tertata dengan baik. Sistem pendidikan menerapkan pola yang baru dapat dilaksanakan dengan baik di sekolah. Pada tahun 2001 pemerintah Indonesia menerapkan otoritas daerah yang juga memberikan pengaruh pada dunia pendidikan karena memindahkan otoritas pemerintah pusat pada pemerintahan didaerah. Sejak saat itu diterapkan Managemen Berbasis Sekolah (MBS), karena sebelumnya managemen pendidikan difokuskan untuk diatur dan diawasi oleh pemerintah pusat. Setiap sekolah memiliki hak dan otoritas untuk menata sistem sekolah agar meningkatkan mutu pendidikan yang disesuaikan berdasarkan undang-undang yang berlaku. Setiap tenaga pendidik yang berkompeten dituntut untuk bertanggung jawab terhadap penerapan managemen berbasis sekolah untuk menata pendidikan di setiap sekolah.

Manajemen berbasis sekolah memberikan kebebasan dalam pengelolaan sekolah, karena adanya kebebasan otoritas dalam menata tatanan pendidikan disekolah yang dapat disesuaikan dengan kepentingan siswa pada kegiatan pembelajaran. Penerapan manejemen berbasis sekolah dapat meningkatkan nilai sumber daya manusia yang dapat mempengaruhi peningkatan kualitas pendidikan. Penerapan manajemen berbasis sekolah memerlukan pengawasan yang ketat oleh unsur-unsur sekolah yang terkait, apakah manajemen berbasis sekolah yang diterapkan sudah dapat meningkatkan mutu pendidikan atau justru belum dapat mencapai tujuan. Tujuan jangka pendek, menengah dan jangka panjang diharapkan dapat di evaluasi dengan baik. Terlebih pada penyusunan program diperlukan keterlibatan dari tenaga pendidik karena secara stuktur guru adalah ujung tombak dari pendidikan dan paling memahami kebutuhan peserta didik.

Menurut Suharsimi (Athiyah, 2019) manajemen berbasis sekolah perlu mencermati pola dilapangan mengenai penerapan pendidikan yang diterapkan 
dalam sekolah terutama 5 aspek yaitu yang meliputi, implementasi manajemen kurikulum, sarana prasarana, keuangan, kesiswaan serta hubungan dengan masyarakat. Penelitian ini menggambarkan tentang implementasi Manajemen Berbasis Sekolah (MBS) yang diterapkan di SMAN 5 Kabupaten Tangerang untuk meningkatkan mutu pendidikan

\section{METODE PENELITIAN}

Penelitian ini menggunakan pendekatan kualitatif dengan metode deskriptif. Metode deskriptif ini menggambarkan dan mengkaji bukti yang diperoleh dari lapangan mengenai implementasi Manajemen Berbasis Sekolah (MBS).

Lokasi penelitian bertempat di SMAN 5 Kabupaten Tangerang yang berlokasi di Jalan Salembaran jaya No. 5, Salembaran, Kecamatan Kosambi, Kab. Tangerang, Banten 15214.

Penelitian ini menggunakan beberapa instrumen, sehingga dapat memudahkan dalam pengumpulan data serta hasil penelitian yang didapat menjadi optimal. Intrumen yang digunakan untuk pengumpulan data pada penelitian ini adalah dengan observasi dan wawancara.

\section{HASIL DAN PEMBAHASAN}

Standar nasional Pendidikan (SNP) adalah sebuah landasan bagi penyelenggaraan standar mutu pendidikan, tetapi upaya tersebut belum mampu dilaksanakan dengan baik sehingga kemudian pemerintah mengganti menjadi Manajemen Berbasis Sekolah (MBS). (Mujiburrahman, Ridha, \& Mahmuddin, 2018). implementasi manajemen dalam pengelolaan pendidikan pada ranah yang lebih sempit mendukung tercapai tujuan pendidikan nasional dengan lebih efektif dan efisien. Manajemen berbasis sekolah menjadi faktor yang penting untuk dilaksanakan di lembaga pendidikan, karena Managemen Berbasis sekolah merupakan sebuah langkah pemberian kewenangan bagi sekolah untuk mengelola penataan pendidikan sesuai dengan kebutuhan tiap-tiap sekolah baik itu peserta didik, tenaga pendidik dan kebutuhan terkait masyarakat sekitar.

Managemen berbasis sekolah merupakan gambaran baru dari managemen pendidikan dimana pemerintah memberikan secara langsung keleluasaan serta kedaulatan pada sekolah. Dimana sekolah dapat mengatur keuangan dan SDM yang dimiliki oleh sekolah disesuaikan dengan kebutuhan setiap sekolah (Anwar, 2018). Perihal ini selaras berdasarkan pemahaman yang dimiliki Sutanto (2018) menyatakan bahwa managemen berbasis sekolah adalah managemen pendidikan yang menggunakan kedaulatan sehingga untuk menghasilkan sebuah keputusan seluruh unsur sekolah memiliki andil, selain itu manajemen ini memberikan kebebasan pada sekolah sebagai wadah untuk memperbaiki mutu pendidikan sesuai dengan tujuan nasional.

$$
\text { Pada konsepnya, manajemen }
$$
berbasis sekolah terdiri dari 3 stakeholder 
yaitu pemerintah pusat, pemeintah daerah, dan sekolah yang memiliki tugasnya masing-masing. Adapun tugas dari pemerintah pusat mengenai MBS yaitu menyusun tujuan yang akan menjadi acuan sekolah, kemudian pemerintah daerah yang berperan mengadakan training pada tenaga pendidik, dan sekolah memiliki tugas merumuskan visi dan misi sesuai dengan kemampuan dari sekolah.

Pendapat dari Nurkholis dalam (Hakim, 2019) menyatakan bahwa terdapat beberapa strategi dalam penerapan Managemen Berbasis Sekolah yaitu setiap sekolah harus memiliki kedaulatan, keterlibatan dukungan orang tua siswa dalam hal keuangan, sikap kepala sekolah yang administratif, pemberlakuan azas demokrasi dalam sekolah, membuat warga sekolah memiliki rasa tanggung jawab, supervisi dari pusat, transparansi dalam sistem keuangan, dan memberikan penyuluhan pada warga sekolah mengenai sistem managemen berbasis sekolah

Penerapan pada managemen berbasis sekolah bertujuan agar sekolah dapat melakukan peningkatan atau perbaikan nilai serta gagasan sekolah melalui pemberian kebebasan oleh pusat yang harus dapat dipertanggung jawabkan (Judin, Harun, \& Ibrahim, 2018). Maka dari itu, sekolah sebagai tempat berlangsungnya belajar mengajar dapat menjadi terobosan baru dalam memperbaiki mutu melalui manajemen berbasis sekolah.

Mutu merupakan hal yang berhubungan dengan sesuatu yang diproduksi oleh suatu lembaga, sedangkan mutu pendidikan yaitu kemampuan sekolah dalam memanfaatkan sumber daya yang dimiliki untuk memperbaiki kapasitas belajar peserta didik. Mutu pendidikan ini dapat tercapai jika adanya kerjasama serta kekompakan dari seluruh warga sekolah baik internal maupun eksternal (Putra, Murniati, \& Bahrun, 2017)

Hasil pendidikan yang bermutu terlihat ketika sekolah memanifestasikan keistimewaan akademik dan keistimewaan non akademik bagi peserta didik yang lulus dari suatu lembaga pendidikan. Keistimewaan akademik dinyatakan dalam prestasi hasil belajar yang didapatkan contohnya yaitu mendapatkan juara umum atau mendapatkan juara kelas. Selanjutnya keistimewaan non akademik atau kegiatan ekstrakulikuler yaitu keterampilan yang didapatkan oleh perserta didik setelah mengikuti suatu kegiatan ektrakulikuler yang diminati contohnya ekstrakulikuler basket, esktrakulikuler debat bahasa inggris, ekstrakulikuler menyanyi, dan lain sebagainya.

Selain untuk meningkatkan mutu peserta didik, kepala sekolah berupaya untuk meningkatkan mutu dari tenaga pendidik, yaitu berupa training dan seminar yang diberikan untuk tenaga pendidik agar menjadi tenaga pendidik yang kompeten dalam bidangnya masing-masing. Penerapan managemen berbasis sekolah menjadi langkah dalam peningkatan kualitas pendidikan di SMAN 5 Kabupaten Tangerang dengan menerapkan manajemen 
kurikulum, manajemen peserta didik, manajemen sarana dan prasarana, mnajemen keuangan serta manajemen hubungan masayarakat.

\section{Penerapan Manajemen Kurikulum}

Implementasi Manajemen dalam bidang kurikulum yaitu proses yang terjadi dalam serangkaian aktivitas atau kegiatan pembelajaran sehingga tujuan tercapai dengan efektif dan efisien. Syafruddin \& Amiruddin (2017) menyatakan bahwa manajemen kurikulum merupakan sebuah langkah pendayagunaan terhadap segala anggaran dan sumber daya manusia yang tersedia dalam sekolah untuk memaksimalkan visi dan misi sekolah. Adapun kegiatan yang ada meliputi planning, organizing, implementation, dan supervision.

Implementasi manajemen kurikulum di SMAN 5 Kabupaten Tangerang, mengacu kepada kompetensi yang disesuaikan dengan keterampilan dalam bidang yang dimiliki oleh masing-masing tenaga pendidik di sekolah. Proses belajar megajar di SMAN 5 Kabupaten Tangerang dilakukan pada hari Senin sampai dengan Jumat dalam satu minggu. Selain itu pihak sekolah selalu membuat kalender akademik setiap tahunnya sebagai acuan terselenggaranya proses pendidikan.

Bidang kurikulum di setiap awal semester mengalokasikan jadwal pelajaran sehingga tenaga pendidik harus mematuhinnya, adapun 1 jam pelajaran yang berlaku sama dengan 45 menit. Jam istirahat yang diberikan pada peserta didik sebanyak 2 kali yaitu pukul 09.15-09.30 dan 12.0012.30 untuk melakukan sholat dzuhur berjamaah dimasjid yang disediakan oleh sekolah. Seluruh kegiatan jadwal belajar mengajar berjalan dengan baik di SMAN 5 Kabupaten Tangerang ini.

\section{Penerapan Manajemen Peserta Didik}

Peserta didik merupakan produk dari sebuah pendidikan. Manajemen peserta didik adalah sebuah pengelolaan terhadap kegiatan yang menyangkut peserta didik. Kegiatan tersebut dimulai dari melakukan penerimaan peserta didik baru, pengembangan karakter pada peserta didik, ketertiban peserta didik, dan lainnya. Biasanya manajemen kesiswaan menyangkut dari peserta didik diterima disekolah, kemudian terlibat dalam proses belajar mengajar, hingga keluar atau lulus dari sekolah tersebut (Fadhilah, 2017)

Adapun tujuan mengelaborasi manajemen dalam bidang kesiswaan yaitu untuk dapat mengembangkan kompetensi, kepribadian, dan karakter peserta didik SMAN 5 Kabupaten Tangerang. Agar dapat mencapai tujuan dari manajemen kesiswaan tersebut, kepala kesiswaan SMAN 5 Kabupaten Tangerang menyerahkan tanggung jawab kepada peserta didik untuk ikut terlibat dalam mendukung sekolah sebagai sekolah Adiwiyata yaitu sekolah yang peduli lingkungan, sehingga peserta didik memiliki kepedulian terhadap lingkungan yang dilakukan setiap minggunya yaitu di hari selasa dan hari jumat. 
Selain itu kegiatan yang dapat mendukung terbentuknya karakter peserta didik di SMAN 5 Kabupaten Tangerang yaitu tadarus atau kegiatan mengaji bersama dilapangan yang dilakukan sebelum proses belajar mengajar berlangsung yaitu dihari rabu, kemudian ada kegiatan muhadoroh yaitu kegiatan dimana peserta didik dan staf sekolah berkumpul dilapangan untuk mendengarkan tausiah dari peserta didik dan membacakan asmaul husna secara bersamasama dimana kegiatan ini dilakukan setiap hari kamis.

Kemudian terdapat program sholat dhuha yang dilakukan bergilir antar kelas setiap harinya guna meningkatkan aspek spiritualitas peserta didik. Semua kegiatan tersebut memiliki tujuan agar peserta didik dapat membangun karakternya, selain itu terdapat beberapa ekstrakulikuler sekolah yang dapat membangun karakter siswa yaitu Pramuka, Osis, PMR (Palang Merah Remaja), GDS (Gerakan Disiplis Siswa), Paskibra, Debat Bahasa Inggris, Tapak Suci, Mading Sekolah, dan lainnya.

\section{Penerapan Manajemen Sarana dan Prasarana}

Menurut Ananda \& Banurea (2017) menyatakan bahwa manajemen sarana dan prasarana merupakan aktivitas pengelolaan fasilitas yang dimiliki sekolah yang dimaksudkan untuk mendukung proses pembelajaran. Sarana dan prasarana yang baik dapat mendukung tercapainya tujuan pembelajaran dengan lebih efektif dan efisien
Instrumen yang secara langsung digunakan SMAN 5 Kabupaten Tangerang untuk membantu proses belajar mengajar dan memberikan efek dalam berjalannya proses belajar mengajar disebut dengan sarana pendidikan yang meliputi ruang kelas, meja kursi, lab, gedung serba guna, masjid, ruang organisasi, UKS, dan alat- alat serta media pendukung lainnya.

Sedangkan Instrumen yang secara tidak langsung dapat memberikan bantuan dalam proses belajar mengajar disebut dengan prasarana pendidikan yaitu meliputi lahan yang dibangun ruang kelas dan lab, halaman sekolah, dan lainnya.. Kegiatan yang dilakukan dalam manajemen sarana dan prasarana pendidikan yaitu meliputi kegiatan planning, procurement, supervision, storage, inventory, arragement, dan deletion.

Implementasi manajemen sarana dan prasarana di SMAN 5 Kabupaten Tangerang ini memiliki fasilitas yang sudah memadai hal ini terlihat dari adanya ruang kelas yang digunakan dalam poses belajar mengajar, lab untuk setiap jurusan, masjid, perpustakaan, parkiran, kantin, meja kursi, papan tulis, media olahraga, dan alat kebersihan.

Fasilitas yang telah disediakan tentunya membutuhkan pemeliharaan, sehingga SMAN 5 Kabupaten Tangerang penyelenggarakan lomba pemeliharaan sarana dan prasarana untuk memotivasi warga sekolah terutama guru dan peserta didik untuk menjaga dan merawat sarana dan prasarana yang tersedia. Bagi kelas yang dapat memenangkan lomba akan diberikan 
piala bergilir. Semakin seluruh warga sekolah ikut secara aktif berpartisipasi dalam lomba tersebut, semakin bertambah rasa memilikinya sehingga dapat bertanggung jawab serta menjaga sarana dan prasarana disekolah.

Hal tersebut menjadi upaya yang dilakukan pihak sekolah untuk mengajak seluruh warganya dalam memperhatikan penggunaan sarana dan prasana yang ada disekolah.

\section{Penerapan Manajemen Keuangan}

Keuangan SMAN 5 Kabupaten Tangerang dikelola mulai dari anggaran yang didapatkan, uraian kebutuhan, pembiayaan sekolah, pemeriksaan terhadap dana, kemudian pembukuan yang dibuat sesuai dengan kebutuhan dari sekolah. Menurut Arwidayanto, Lamatenggo, \& Sumar (2017) menyatakan bahwa manajemen keuangan yaitu seluruh aktivitas yang menyangkut pengaturan keuangan disekolah, dengan tujuan agar sekolah memiliki kedisiplinan dalam tata laksana bidang keuangan. Adanya manajemen keuangan diharapkan dapat mendukung berjalannya pembelajaran yang efektif dan efisien.

Penerapan manajemen keuangan sekolah dapat memberikan efek atau dampak dalam peningkatan mutu pendidikan, karena dalam melaksanakan setiap aktivitas tentunya dibutuhkan pengelolaan keuangan yang baik untuk mendanai aktivitas yang direncanakan maupun aktivitas yang sifatnya insidental. Sistem keuangan yang terkelola dengan baik secara tidak langsung dapat menunjang pengelolaan pendidikan yang efektif dan efisien.

Sumber keuangan yang ada di SMAN 5 Kabupaten Tangerang bersumber dari Pemerintah seperti Dana Bos dan dana Bosda yang disiapkan oleh pemerintah daerah, yang nantinya sumber dana tersebut akan digunakan sebagai penunjang proses belajar mengajar contohnya pemenuhan sarana dan prasarana yang dibutuhkan oleh peserta didik, pemeliharaan sarana prasarana, kegiatan-kegiatan yang mendukung proses pendidikan dan lain lain. Sistem pengelolaan keuangan telah disepakati bersama dengan komite sekolah untuk adanya tranparansi mengenai rincian dana yang masuk atau diterima dan keluar, menurut komite sekolah anggaran biaya telah diatur dengan terstruktur dan terpadu oleh sekolah dan dapat dipertanggung jawabkan oleh sekolah.

\section{Penerapan Manajemen Hubungan Masyarakat}

Manajemen Berbasis Sekolah adalah sebuah pengelolaan pendidikan yang membutuhkan adanya kerjasama antara unsur-unsur sekolah. Yang termasuk dalam unsur tersebut yaitu masyarakat sekitar seperti tokoh masyarakat dan badan swadaya masyarakat. Manajemen hubungan masyarakat termasuk dalam elemen penting, karena untuk menarik perhatian masyarakat dalam bekerjasama dengan sekolah sangatlah sulit, Oleh sebab itu dengan adanya manajemen hubungan masyarakat diharapkan dapat menjalin kerjasama dengan seluruh masyarakat 
untuk berpartisipasi dalam meningkatkan serta memperbaiki mutu pendidikan (Hakim, 2019)

Dengan cara melibatkan masyarakat sekitar sekolah dalam program akan mencapai keyakinan yang tinggi dan menambah afeksi masyarakat terhadap sekolah terutama perbaikan mutu pendidikan, dan masyarakat nantinya mendapatkan dampak perkembangan atau umpan balik yang dihasilkan oleh sekolah. Peran dari masyarakat sekitar yang tinggal dilingkungan sekolah memiliki efek sangat besar terhadap seluruh warga sekolah, maka dari itu sekolah harus memiliki hubungan yang baik dengan masyarakat sekitar terlebih untuk melibatkan masyarakat sekitar dalam program atau sistem pendidikan disekolah.

\section{SMAN 5 Kabupaten Tangerang} merupakan melibatkan masyarakat sekitar untuk meningkatkan mutu pendidikan, yaitu dengan menerima guru yang berasal dari lingkungan sekolah untuk membantu dalam proses belajar mengajar kemudian banyak masyarakat sekitar juga yang membuka warung serta parkiran untuk peserta didik.

Kegiatan pertemuan secara personal antara sekolah dan masyarakat baik tokoh masyarakat, ulama dan anggota masyarakat dilakukan guna mendapatkan masukan bagi pembangunan sekolah yang labih baik. Kegiatan ini berbentuk diskusi informal yang membahas terkait program-program yang akan dijalankan oleh sekolah. hal tersebut juga sebagai langkah sosialisasi terkait program yang akan sekolah laksanakan.
Mengundang wali murid diawal proses penerimaan siswa baru menjadi langkah untuk membangun hubungan dengan masyarakat. Kegiatan ini ditujukan untuk membuat kolabirasi yang baik antara program pendidikan di sekolah juga program pendidikan dirumah. Dimana pihak orang tua dapat memantau perkembangan anaknya disekolah, dan guru terbantu untuk mengawasi peserta didik saat mereka ada di rumah.

Hubungan sekolah dan masyarakat sangat penting dalam penyelenggaraan pendidikan. Pemberian konseling juga dilakukan bukan hanya bagi siswa yang bermasalah akan tetapi juga dilakukan untuk orang tua. Konseling ini agar orang tua juga ikut terlibat dalam pendidikan dan pengawasan siswa, karena sejatinya siswa bukan hanya anggota di sekolah, mreka pun merupakan anggota di masyarakat.

Hubungan baik juga dilakukan antara sekolah dengan pusat kesehatan daerah setempat. Hal ini untuk menunjang terkait aspek kesehatan siswa, khususnya siswa wanita. Kerjasama ini diwujudkan dalam bentuk sosiasilasi kesehatan dari puskesmas tentang kesehatan remaja putri.

\section{KESIMPULAN}

Manajemen Berbasis Sekolah (MBS) adalah hasil produk dari pembaruan pendidikan yang menyerahkan otoritas secara keseluruhan pada pihak sekolah mengenai pengaturan pendidikan. Adapun penerapan MBS dalam bidang kurikulum di SMAN 5 Kabupaten Tangerang telah terealisasikan 
sesuai visi dan misi sekolah yang telah ditetapkan. Kemudian MBS dalam bidang kesiswaan meliputi kegiatan penerimaan dan untuk mewujudkan siswa yang berkarakter. Penerapan MBS dalam bidang keuangan telah dikelola dengan baik dan menerapkan sistem transparansi pada komite sekolah. Selanjutnya MBS dalam bidang sarana dan prasaran dikelola dengan baik yaitu dengan meliputi prosedur yang telah ditetapkan sekolah. Terakhir MBS dalam bidang hubungan masyarakat dimana SMAN 5 Kabupaten Tangerang memiliki hubungan yang baik dengan masyarakat yang berada dalam lingkungan sekolah bahkan ada beberapa warga yang bekerja disekolah.

\section{DAFTAR PUSTAKA}

Ananda, R. \& Banurea, O.K. 2017. Manajemen Sarana dan Prasarana Pendidikan. Medan: Widya Puspita.

Anwar, M. 2018. Manajemen Berbasis Sekolah. Ekspose: Jurnal Penelitian Hukum dan Pendidikan, 17 (2), 601614

Arwildayanto. Lamatenggo, N. \& Sumar, W.T. 2017. Manajemen Keuangan dan Pembiayaan Pendidikan. Bandung: Widya Padjadjaran Anggota IKAPI JABAR.

Athiyah, U.C. 2019. Implementasi Manajemen Berbasis Sekolah Sebagai Alternatif Desentralisasi Pendidikan di MAN 4 JAKARTA. Andragogi Jurnal Diklat Teknis, 7 (1), 130-145.

Fadhilah. 2017. Manajemen Kesiswaan di Sekolah. Jurnal Studi Pemilihan, Riset dan Pengembangan Pendidikan Islam, 5 (2), 103-120.

Hakim, L. 2019. MBS Konteporer Teori dan Praktik. Jambi: Timur Laut Aksara.

Hakim, M.N. 2019. Manajemen Hubungan Masyarakat Dalam Mengembangkan Lembaga Pendidikan (Studi Kasus di SMK Negeri 1 Dlanggu Mojokerto).
Jurnal Manajemen Pendidikan Islam, 4 (1), 121-139.

Judin, M. Harun, C.Z. \& Ibrahim, S. 2018. Implementasi Manajemen Berbasis Sekolah Dalam Peningkat Mutu Pendidikan pada MTSN GrongGrong Kabupaten Pidie. Jurnal Magister Administrasi Pendidikan Pascasarjana Universitas Syiah Kuala, 6 (2), 117-122.

Mujiburrahman. Ridha, M. \& Mahmuddin. 2018. Manajemen Berbasis Sekolah Berorientasi Pelayanan Publik: Teori dan Implementasinya. Yogyakarta: Zahir Publishing.

Putra, R.S. Murniati, A.R. \& Bahrun. 2017. Strategi Peningkat Mutu Pendidikan pada SMA Negeri 3 Meulaboh Kecamatan Johan Pahlawan Kabupaten Aceh Barat. Jurnal Magister Administrasi Pendidikan Pascasarjana Universitas Syiah Kuala, 5 (3), 161-166.

Sari, D, N. Bafadal, I. \& Wiyono, B.B. 2018. Pelaksanaan Supervisi Manajerial Dalam Rangka Implementasi Manajemen Berbasis Sekolah. Jurnal Administrasi dan Manajemen Pendidikan, 1 (2),213-321.

Sutanto, P. 2018. Manajemen Berbasis Sekolah Sekolah Menengah Atas. Jakarta: Direktorat Pembina SMA.

Syafruddin. \& Amiruddin, M.S. 2017. Manajemen Kurikulum. Medan: Perdana Publishing. 